\title{
PELAKSANAAN DIYAT DALAM KERANGKA PERUNDANGAN DI MALAYSIA: CABARAN FIQH SEMASA
}

\section{Implementation of Diyat in Legal Framework in Malaysia: Challenge to the Contemporary Islamic Jurisprudence}

\author{
Paizah Ismail *
}

\begin{abstract}
Diyat, or "Blood Money" is a sum to be paid by the criminal or his family in cases of "Qisas and Diyat", which generally concerns "Murder or causing bodily harm". However, the implementation of this law seems very difficult, if not impossible these days due to the change in values and society. This article analyses the way how to overcome these problems by a method known among some Islamic Scholars as "Contemporary Islamic Jurisprudence". Among the findings of this study are, even though the word of Allah and the sayings of Prophet Muhammad are absolute and universal the interpretations of the jurists on the verses and hadith are not the same. It has always been influenced, among others, by the realities of life according to the time and location. Therefore, to implement such laws nowadays the classical juristic on the related verses of the Quran and the hadith of the Prophet Muhammad should be revisited by taking into account the reality of current life and society.
\end{abstract}

Keywords: Diyat, Blood Money, Islamic Law, Contemporary Fiqh, Reinterpretation

* Konsultan, Jabatan Fiqh \& Usul, Akademi Pengajian Islam Universiti Malaya, Kuala Lumpur, paizahismail@um.edu.my. 


\section{PENDAHULUAN}

Dalam sistem perundangan Islam diyat merupakan bayaran yang dikenakan terhadap pesalah dalam kes-kes kematian atau kecederaan. Dalam sesetengah kes ia merupakan hukuman asal kepada kesalahan berkenaan. Tetapi dalam kes-kes yang lain pula ia merupakan hukuman alternatif kepada hukuman qisas.

Dalam kitab-kitab fiqh klasik, terdapat berbagai definisi yang diberikan terhadap hukuman yang bersifat bayaran ini. Ada yang mengatakan ianya suatu ganti rugi. ${ }^{1}$ Bagi sesetengah para fuqaha lain pula ia bukan ganti rugi tetapi bayaran yang dikenakan kerana melakukan jenayah membunuh atau mencederakan. ${ }^{2}$ Ini bermaksud, para fuqaha berbeza pendapat, sekurang-kurangnya dalam menggunakan istilah, sama ada diyat merupakan ganti rugi atau hukuman. Berasaskan kepada perbezaan para fuqaha klasik dalam menggunakan istilah ini kita dapati para fuqaha semasa juga berbeza pendapat mengenainya. ${ }^{3}$

Secara dasarnya ia akan dibayar oleh pesalah itu sendiri, iaitu apabila diyat yang dikenakan adalah sebagai hukuman terhadap perbuatan membunuh secara sengaja. ${ }^{4}$ Tetapi dalam beberapa keadaan ia akan dibayar oleh keluarganya, atau yang diistilahkan sebagai 'āqilah, iaitu dalam kes-kes pembunuhan dengan secara tidak sengaja, ${ }^{5}$ malah mungkin oleh kerajaan yang memerintah, iaitu dalam kes-kes penjenayah berkenaan tidak mempunyai 'àqilah atau 'āqilahnya itu tidak mampu untuk membayar diyat berkenaan. ${ }^{6}$

1 Lihat: Abū al-Ḥasan al-Mālikī, Kifāyat al-Ṭālib (Bayrūt: Dār al-Fikr, 1412), 2:387.

2 Lihat: Al-Būṭ̂̄, Rawd al-Murabbā' (Riyāḍ: Maktabah al-Riyāḍ alHādīthah, 1390) 3:276; Al-Ramlī, Nihāyah al-Muhtāj (al-Qāhirah: Mușțafā al-Halabī, t. t.), 6:310.

3 Bahansī, al-Diyahfíal-Sharī'ahal-Islāmiyyah (al-Qāhirah: Maktabah al-Anglow al-Islāmiyyah, 1967) 10; Wahbah al-Zuhaylī, al-Fiqh alIslāmī wa Adillatuh (Bayrūt: Dār al-Fikr al-Mu'āṣir, 1997), 7:5702.

4 Lihat: Al-Zuhaylī, al-Fiqh al-Islāmī wa Adillatuh, 7:5729.

5 Lihat: Misalnya, al-Shāfi‘̄i, al-Umm (al-Qāhirah: Dār al-Ghad, 1990), 171.

6 Lihat: Al-Shawkānī, Nayl al-Awțār (Bayrūt: Dār al-Fikr, 1983), $7: 190$. 
Jumlah bayaran yang dikenakan pula adalah berbezabeza mengikut kes. Sehubungan dengan ini para fuqaha mengklasifikasikan diyat kepada dua kategori. Pertama, diyat berat (diyat mughāllazah) dan kedua pula diyat ringan (diyat mukhaffafah). Kategori pertama dikenakan dalam kes-kes kematian atau kecederaan yang dilakukan secara niat (al- 'amd/ shibh al-'amd), sementara kategori kedua pula dikenakan dalam kes-kes kematian atau kecederaan yang dilakukan secara tanpa niat (al-khațā'/shibh al-khațā'). ${ }^{7}$

Mengikut pandangan majoriti para fuqaha klasik, ia perlu dibayar dalam bentuk unta berasaskan spesifikasi yang ketat. Sementara cara pembayarannya pula sama ada sekaligus atau secara beransur-ansur mengikut perbezaan kes berkenaan. Diyat berat (mughällazah) dibayar dalam bentuk 100 ekor unta yang terdiri daripada berbagai peringkat umur. Sementara diyat ringan (mukhaffafah) pula dibayar dalam bentuk 100 ekor unta juga tetapi dalam pecahan umur yang berbeza. ${ }^{8}$ Namun ada juga para fuqaha yang berpendapat ia boleh dibayar dalam bentuk mata wang emas dan perak. Bagaimanapun mereka berbeza pendapat tentang kadar yang perlu dibayar. Ada yang mengatakan 1000 dinar emas atau 12000 dirham perak tanpa mengambil kira diyat berat atau diyat ringan. ${ }^{9}$ Pada pendapat lain pula diyat ringan hanya pada kadar $2 / 3$ daripada jumlah berkenaan sahaja. ${ }^{10}$

Bagaimanapun, diyat ini bukanlah satu istilah yang tunggal bagi hukuman yang dikenakan dalam kes-kes berkenaan. Terdapat berbagai istilah lain yang biasa digunakan oleh para fuqaha klasik bagi merujuk kepada kes-kes tertentu. Antara istilah-istilah tersebut ialah 'arsh, hukümah, dan ghurrah. Mengikut para fuqaha, istilah 'arsh digunakan bagi maksud diyat yang dibayar dalam kes kecederaan. ${ }^{11}$ Hukümah pula bermaksud bayaran yang

\footnotetext{
7 Lihat: Al-Zuhaylī, al-Fiqh al-Islāmī wa Adillatuh, 5708.

8 Lihat: Al-Zuhaylī, al-Fiqh al-Islāmī wa Adillatuh, 5709.

9 Lihat: Al-Jașșāṣ, Ahkām al-Qur'ān (Bayrūt: Dār al-Fikr, 1993), 2:332-333.

10 Lihat: Aḥmad Husārī, al-Siyāsah al-Jaza'iyyah (Bayrūt: Dār al-Jayl, 1993), 3:711.

11 Lihat: Ibn 'Ābidīn Muhammad Amīn, Hāshiyah Radd al-Muhtāar 'alā al-Dur al-Mukhtār (al-Qāhirah: al-Bābī, 1966), 6:573.
} 
dikenakan dalam kes kecederaan ringan. ${ }^{12}$ Manakala ghurrah pula digunakan bagi tujuan bayaran yang dikenakan dalam kes-kes yang melibatkan anak dalam kandungan. ${ }^{13}$

Bagi melaksanakan hukuman seperti ini dalam realiti perundangan di Malaysia sekarang banyak persoalan yang perlu diselesaikan terlebih dahulu. Bagaimanapun tidak semua jawapannya ada dalam fiqh klasik kerana jarak masa yang terlalu lama di antara waktu fiqh itu ditulis dan sekarang ini. Selain itu, terdapat juga perbezaan realiti hidup di antara negara-negara di timur tengah yang menjadi latar belakang budaya kepada penulisan berkenaan dan masyarakat tempatan yang menjadi wadah kepada pelaksanaannya sekarang. Semuanya ini memerlukan penilaian semula terhadap beberapa aspek yang mungkin dahulunya tidak pernah berbangkit. Penilaian semula ini boleh dilakukan melalui apa yang disebut sekarang ini sebagai "Fiqh Semasa" atau disebut juga sebagai "Fiqh Kontemporari".

\section{KEPERLUAN KEPADA FIQH SEMASA}

Keperluan kepada hukum Islam semasa bagi menjawab persoalan hidup semasa dalam masyarakat Islam pada hari ini, seperti mana yang berbangkit di atas sangat dirasakan. Di bawah pengaruh dunia baru dengan segala kemajuannya, baik dari segi ekonomi, sosial mahupun sains dan teknologi, hampir semua perkara dalam kehidupan moden sekarang ini seolah-olah telah berubah.

Kalau syariat Islam hanyalah suatu agama semata-mata, segala perubahan ini mungkin tidak merupakan cabaran besar terhadap corak amalannya. Kerana ritual keagamaan biasanya tidak tertakluk kepada apa-apa perubahan masyarakat memandangkan sifat dan nilainya yang dogmatik. Tetapi Islam bukan satu agama sematamata dalam konsep yang sempit di atas. Ianya suatu sistem hidup. Oleh kerana hidup manusia ini berkembang maka cabaran yang terpaksa dihadapi ialah pengembangan tafsiran dan amalannya agar sesuai dengan keperluan setiap perkembangan yang ada.

\footnotetext{
12 Lihat: Wahbah al-Zuhaylī, Nazariyyah al-Ḍamān (Damshiq: Dār alFikr, 1998), 328.

13 Lihat: Al-Zuhaylī, al-Fiqh al-Islāmī wa Adillatuh, 7:5771.
} 
Sifat semasa atau kontemporari ini ditegaskan oleh ramai para fuqaha semasa, termasuk al-Qaraḍāwī. ${ }^{14}$ Beliau menegaskan bahawa salah satu daripada keistimewaan fiqh Islam ialah kemampuannya untuk berkembang dan diperbaharui serta sifatnya yang fleksibel yang memungkinkannya menghadapi apa sahaja masalah yang timbul tanpa mengira saiznya.

Sehubungan dengan ini, al-Qaraḍāwī menekankan bahawa keperluan kepada ijtihad baru yang berasaskan kepada nilainilai kontemporari ini lebih nyata keperluannya pada masa ini berbanding dengan masa-masa atau zaman sebelum ini. Ini memandangkan adanya perubahan besar dalam masyarakat hidup manusia yang terjadi sejak berlakunya revolusi perindustrian dan kemajuan teknologi yang begitu pesat sekali, malah fenomena globalisasi yang telah menjadikan dunia sebagai sebuah kampung kecil. $^{15}$

Bagaimanapun, pemikiran tentang fiqh kontemporari, atau hukum Islam semasa ini bukan perkara baru. Di zaman awal Islam ia terdapat dalam berbagai bentuk. Antaranya syariat Islam sendiri tidak diturunkan oleh Allah secara sekaligus. ${ }^{16}$ Muhammad al-Khuḍr $\overline{1}^{17}$ mengulas kedudukan ini dengan menyebut perkaitan metod penurunan secara beransur-ansur itu dengan keadaan semasa masyarakat Arab pada waktu itu. Mengikut beliau, dalam kehidupan masyarakat berkenaan terdapat adat kebiasaan buruk yang sebati dan sukar sekali diubah. Kerana itu, metod "tadarruj" ini digunakan bagi menghapuskan kebiasaan buruk berkenaan secara berperingkat.

Sebagai contoh, pengharaman arak berlaku sekurang-kurangnya dalam tiga tahap. Sebabnya ialah untuk mengambil kira keadaan semasa yang mempengaruhi proses kejayaan pensyariatan itu

14 Yūsuf al-Qaraḍāwī, al-Fiqh al-Islāmì baina al-Iṣālah wa al-Tajdìd, ed. ke-2 (al-Qāhirah: Maktabah Wahbah, 1999), 22.

15 Al-Qaraḍāwī, al-Fiqh al-Islāmī baina al-Ișālah wa al-Tajdìd.

16 Lihat: Al-Khāțib al-Tabriz̄i, Mishkāt al-Mașābīh, ed. Naṣr al-Dīn alAlbānī (Bayrūt: al-Maktab al-Islāmī, 1969), 1:425.

17 Muhammad al-Khuḍrī, Tārīkh al-Tashrī‘ al-Islāmī, ed. ke-6 (alQāhirah: Maktabah al-Tijāriyyah al-Kubrā, 1964), 19-20. 
sendiri. Pengambilkiraan realiti hidup semasa ini merupakan asas paling utama kepada prinsip fiqh kontemporari. ${ }^{18}$

Ḥasan Șubḥ̄ Aḥmad ${ }^{19}$ menyebut, salah satu ciri syariat Islam ialah bersikap mudah (al-Taysir) terhadap para mukallaf. Sebabnya, kerana mengambil kira realiti para mukallaf itu sendiri supaya penugasan atau "taklif" yang terdapat dalam Islam itu tidak terlalu membebankan.

Ayat-ayat al-Quran sendiri berkali-kali menegaskan prinsip bertoleransi dalam keadaan sukar ini. Antaranya penegasan penafian terhadap ketentuan hukum yang boleh menjadikan seseorang itu berada dalam dilema atau keadaan serba salah (haraj), ${ }^{20}$ objektif untuk memberi kemudahan dan tidak untuk menyukarkan, ${ }^{21}$ untuk memberi keringanan memandangkan manusia itu makhluk yang lemah ${ }^{22}$ dan seterusnya penegasan tiada tugasan di luar kemampuan.

Mengikut Muḥammad Yūsuf Mūsā $\bar{a}^{23}$ perbuatan mukallaf yang menjadi subjek kepada fiqh itu merupakan sesuatu yang berubah dan berkembang dari masa ke semasa. Oleh itu kita boleh merumuskan bahawa salah satu daripada faktor yang memperkembangkan pengajian hukum Islam (al-figh) itu ialah tabiat atau nature hidup manusia itu sendiri, iaitu sentiasa berubah dan berkembang selaras dengan peristiwa dan kejadian yang berlaku.

Mengikut beliau lagi, perbezaan begitu ketara sekali antara kehidupan di zaman Rasulullah SAW di Semenanjung Tanah Arab dengan apa yang berlaku selepas wafat Baginda di mana dunia Islam sudah menjadi begitu luas. Di zaman Rasulullah SAW masyarakat Islam hanya terdiri daripada orang-orang Arab sahaja. Adat dan tradisi mereka tidak banyak berbeza. Kalau ada pun hanya sedikit sahaja di antara para penduduk Mekah dengan

18 Lihat: 'Umar Sulaymān al-Ashqar, Tārīkh al-Fiqh al-Islāmī, ed. ke-3 ('Ammān: Dār al-Nafā'is, 1991), 46-47.

19 Hasan Șubḥ̄ Aḥmad, al-Madkhal ilā al-Fiqh al-Islāmī (al-Qāhirah: Mațba'ah al-Risālah, 1971), 43-50.

20 Al-Haj (22): 278; al-Baqarah (2): 158.

$21 \quad$ Al-Baqarah (2): 286.

22 Al-Mā'idah (5): 6.

23 Muhammad Yūsuf Mūsā, Tārīkh al-Fiqh al-Islāmī (al-Qāhirah: Dār al-Kitāb al-'Arabī, 1958), 30. 
penduduk Madinah. Tetapi kini perkembangan Islam yang berlaku dengan begitu cepat sekali itu telah merangkumi negara-negara besar di sekeliling semenanjung tanah arab, seperti Iraq, Syria, Mesir, negara-negara Utara Afrika dan banyak lagi.

Setiap negara atau daerah ini, jelas Yūsuf Mūsā lagii mempunyai corak hidup dan tamadun yang tersendiri. Masingmasing mempunyai adat dan tradisi yang sangat berbeza antara satu sama lain berbanding dengan perbezaan yang ada di antara penduduk kota Mekah dan Kota Madinah sebelum itu.

Perbezaan adat atau resam hidup di antara penduduk Mekah dan Madinah telah melahirkan kesan hukum yang tersendiri. AlBukhārī dan Muslim ${ }^{25}$ meriwayatkan apabila Baginda Rasulullah SAW mendapati ada suatu kebiasaan di kalangan penduduk Madinah, iaitu bermualamat atau melakukan urusniaga berasaskan konsep pasaran kehadapan yang dikenali sebagai "Bay' al-Salām". Baginda memperakui urusniaga seperti itu dengan memberi syarat ia perlu berasaskan spesifikasi yang benar-benar jelas dan terperinci. Sebagaimana dimaklumi umum, konsep pasaran kehadapan ini merupakan perkecualian daripada prinsip umum yang tidak membenarkan urusniaga yang melibatkan barangan yang belum ada, seperti mana yang terdapat dalam hadis Rasulullah

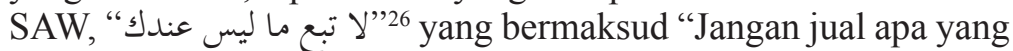
tidak ada pada kamu".

Maka kalaulah perbezaan hidup dan adat resam yang sedikit itu telah memberi kesan kepada perubahan hukum, apatah lagi perbezaan besar yang terdapat di antara daerah-daerah Islam yang luas itu. Apalagi kalau dilihat kepada realiti perbezaan zaman. Mengikut Muḥammad Yūsuf Mūsā lagi, kejadian-kejadian terus berlaku dan persoalan-persoalan terus timbul. Semuanya ini memerlukan jawapan. Bagi memenuhi keperluan ini wahyu bertindak sebagai idealisme sementara realiti hidup memainkan peranan sebagai wadah di mana idealisme itu diaplikasikan. ${ }^{27}$

24 Muhammad Yūsuf Mūsā, Tārīkh al-Fiqh al-Islāmī, 31.

25 Al-Bukhārī, Șaḥ̄ḥ al-Bukhārī (Bayrūt: Dār Ihyyā' al-Turāth al'Arabī), 387; Muslim, Șaḥ̄h Muslim (Bayrūt: Dār Iḥyā' al-Turāth al-'Arabī, 2000), 709.

26 Hadis riwayat Abū Dāwūd, al-Nasā'̄̄ dan Ibn Mājah.

27 Muhạmad Yūsuf Mūsā, Tārīkh al-Fiqh al-Islāmī, 31. 
Al-Shahrastān̄̄, dalam memperkatakan kewajipan berijtihad dan syarat-syaratnya telah menyentuh tentang pemikiran asas ini, iaitu realiti hidup yang mempengaruhi perkembangan hukum atau dalam konteks perbincangan kita di sini, pemikiran tentang hukum Islam semasa atau fiqh kontemporari.

Mengikut beliau, secara umumnya, kita benar-benar tahu dan yakin bahawa peristiwa dan kejadian yang berhubung dengan ibadat dan urusan hidup manusia tidak terhitung banyaknya. Kita juga tahu bukan semua kejadian atau kes itu ada nas yang menerangkan hukumnya secara khusus. Malah mustahil hal seperti itu boleh berlaku, kerana bilangan nas syarak sangat terhad sedangkan kejadian dan peristiwa pula terus berlaku tanpa penghujung. Realiti ini memberi kefahaman kepada kita tentang perlunya ijtihad dalam menentukan hukum bagi setiap kejadian dan peristiwa yang berlaku. ${ }^{28}$

Lahirnya golongan-golongan tertentu dalam pengajian hukum (al-madāris al-fiqhiyyah) yang kemudiannya berkembang menjadi aliran atau mazhab (al-madhāhib al-fiqhiyyah) juga mempunyai perkaitan yang rapat dengan masalah hukum Islam semasa atau fiqh kontemporari ini.

Sebagaimana maklum, antara corak perkembangan pengajian hukum Islam (al-figh) selepas kewafatan Rasulullah SAW sehinggalah kepada zaman kemuncaknya ialah kelahiran aliran (al-madāris) dan mazhab (al-madhāhib). Golongan-golongan seperti itu terdapat di serata tempat seperti Mekah, Madinah, Kufah, Mesir, Syam dan sebagainya. Ia dipimpin oleh golongan fuqaha tertentu yang mempunyai corak pemikiran yang agak berbeza dari satu aliran ke satu aliran yang lain. Seperti mana yang disebut di atas, antara faktor yang mempengaruhi corak pemikiran ini ialah persekitaran hidup masing-masing yang merupakan satu aspek yang sangat penting dalam konsep hukum Islam semasa atau yang diistilahkan sekarang sebagai fiqh kontemporari.

Meskipun pada mulanya kebanyakan mereka ini terdidik di bawah madrasah (sekolah) yang sama iaitu "madrasah al-rasull" tetapi kemudiannya mempunyai pandangan hukum yang kadang-

28 Al-Shahrastānī, al-Milal wa al-Niḥal, 34. 
kadang berbeza kerana, antara lain berada dalam persekitaran hidup yang berbeza.

Mengulas fenomena ini Muḥammad Yūsuf Mūsā menyebut, setiap golongan para fuqaha tersebut berada di negeri-negeri yang mempunyai corak ketamadunan yang tersendiri dengan segala budaya, adat resam dan tradisi undang-undang masingmasing. Semuanya ini telah memainkan peranan yang aktif dalam membina mentaliti para fuqaha berkenaan sesuai dengan corak ketamadunan yang ada. Begitu juga persoalan serta peristiwa yang tidak pernah mereka alami sebelum itu. Di bawah pengaruh realiti hidup yang berbagai-bagai inilah berbagai golongan para fuqaha itu melakukan ijtihad mereka dengan cara merealisasikan idealisme Islam yang terdapat dalam al-Quran dan al-Sunnah dalam realiti kehidupan masyarakat masing-masing. ${ }^{29}$

Atas sikap menghormati prinsip kontemporari inilah juga alImām Mālik menolak cadangan Khalīfah Hārūn al-Rashīd untuk menjadikan kitab al-Muwattă' hasil karangan itu sebagai teks undang-undang yang tunggal yang perlu diikuti oleh semua orang. Kata al-Imām Mālik:

"Tidak ada sebab untuk memaksa orang ramai mengamalkan apa yang ada dalam kitab al-Muwațtā' . Kerana para sahabat Rasulullah SAW telah keluar ke merata daerah selepas kewafatan Baginda dan telah meriwayatkan hadis didaerah-daerah itu. Oleh kerana itu setiap daerah ada keilmuan yang tersendiri. Sedangkan Rasulullah SAW sendiri pernah bersabda: Perbezaan pendapat di kalangan umatku merupakan suatu rahmat". ${ }^{30}$

Malah, al-Imām Mālik walaupun dikritik oleh banyak pihak, ${ }^{31}$ tetap menganggap amalan penduduk Madinah ('amal ahl al-

\footnotetext{
29 Al-Shahrastān̄, al-Milal wa al-Niḥal, 50-51.

30 Kubrā Zādah Aḥmad Ibn Muștafā, Miftāḥ al-Sa 'ādah (Hidrabad: t. p., 1356H), 2:87.

31 Lihat surat al-Imām Mālik kepada al-Imām al-Layth Ibn Sa'd dalam al-Qāḍ̄ 'Iyāḍ, Tartīb al-Madārik (al-Qāhirah: t. p.), 34 dan jawapan al-Imām al-Layth terhadap surat tersebut dalam: Ibn al-Qayyim alJawziyyah, I'lām al-Muwaqqi 'īn (al-Qāhirah: Maktabah al-Kulliyyāt al-Azāhariyyah, 1968), 3:83-88.
} 
Madinah) sebagai sumber hukum memandangkan di situlah tempat wahyu diturunkan dan Rasulullah SAW telah merealisasikan wahyu-wahyu berkenaan sampai kepada peringkat membudayakan penduduk di situ dengan budaya wahyu.

Jelaslah, pengaruh keadaan semasa dan setempat tetap mewarnai keputusan para fuqaha tentang hukum Islam dan terus berkembang bersama perkembangan fiqh itu sendiri dengan berbagai mazhab yang terdapat di dalamnya.

Perbezaan pendapat di antara mazhab Shafii dan mazhab Hanafi misalnya, antara lain diwarnakan oleh perbezaan persekitaran hidup yang dialami oleh kedua-dua tempat di mana mazhab-mazhab itu tumbuh dan berkembang. Sebagaimana maklum, mazhab Hanafi bermula dan berkembang di Iraq, sementara mazhab Shafii pula bermula di Madinah dan kemudiannya berkembang di Mekah, Baghdad dan di Mesir. Malah terdapat juga pendapat-pendapat yang berbeza dalam satu mazhab yang sama kerana dipengaruhi oleh perbezaan persekitaran hidup. Antara contohnya perbezaan antara pandangan lama (al-qawl al-qadìm) dengan pandangan baru (al-qawl al-jadìd) dalam mazhab Shafii kerana perbezaan persekitaran hidup antara kota Baghdad yang menjadi tempat berkembang qawl qadìm dan Kaherah yang menjadi tempat di mana qawl jadì $d$ berkembang. ${ }^{32}$

Dalam metodologi pengajian hukum Islam atau Ușūl alFiqh kedudukan persekitaran hidup atau keadaan semasa ini dibincangkan terutama sekali dalam huraian para fuqaha tentang sumber-sumber sekundar bagi hukum Islam, terutama kelaziman (al-'urf) dan kepentingan masyarakat (al-mașlaḥah).

Begitulah konsep hukum Islam semasa ini. Bukan sekadar satu aliran pemikiran dalam pengajian hukum Islam, tetapi lebih merupakan suatu realiti yang diambilkira oleh semua pihak dari berbagai aliran dan mazhab. Kenyataan ini disokong oleh fakta sejarah seperti mana yang dibentangkan di atas.

Hanya apabila pengajian hukum Islam mengalami kejumudan dan ijtihad yang sebenar tidak lagi dilakukan, pengaruh keadaan semasa ini mula luntur dan kemudiannya terus hilang. Ini kerana

32 Lihat: Muhammad Abū Zahrah, F̄̄ Tārīkh al-Madhāhib al-Fiqhiyyah (al-Qāhirah: Dār al-Fikr al-'Arab̄i, t. t.), 178-180 dan 249-298. 
dalam keadaan seperti itu pengembangan pengajian berkenaan hanya berlaku dalam bentuk keperpustakaan sahaja dan tiada kerja-kerja lapangan dilakukan. Segala pandangan para fuqaha terdahulu telah dilihat sebagai kemuncak yang tidak ada lagi yang boleh mengatasinya dan tidak lagi boleh dinilai, termasuklah berasaskan kepada perkembangan baru masyarakat.

\section{ANTARA KESALAHAN JENAYAH DAN KESALAHAN SIVIL}

Antara persoalan paling awal yang perlu dijawab berasaskan kerangka perundangan yang ada di Malaysia sekarang ialah sama ada diyat merupakan hukuman jenayah atau ganti rugi sivil, iaitu yang dikenali sebagai Tort? Terutama sekali dalam konteks pelaksanaan hukum diyat dalam kerangka perundangan di Malaysia sekarang persoalan ini sangat penting. Kerana pembezaan antara kesalahan sivil dan kesalahan jenayah mempunyai latar belakang pemikiran yang mantap dalam undang-undang Malaysia sekarang, juga dalam fiqh Islam. ${ }^{33}$ Berasaskan pembezaan tersebut, tanggungjawab jenayah sentiasa dibezakan dengan tanggungjawab sivil. Pertama bertujuan untuk menghukum penjenayah berkenaan sementara yang kedua bertujuan untuk membayar ganti rugi kepada mangsa.

Malah, persoalan ini tidak bersifat akademik semata-mata, kerana ia melibatkan soal prosedur. Maksudnya, prosedur mana yang perlu digunakan dalam kes-kes berkenaan, sama ada prosedur jenayah atau prosedur sivil? ${ }^{34}$ Sekiranya kesalahan yang melibatkan hukuman diyat itu dianggap sebagai kesalahan jenayah ia dibicarakan mengikut prosedur jenayah, dan kalau ia dinggap sebagai kesalahan sivil, iaitu Tort maka prosedur sivil akan digunakan.

Persoalan ini timbul kerana sifat yang terdapat pada diyat itu sendiri sebagai satu jenis hukuman yang tertentu. Ia meskipun

33 Lihat: Muhammad Salīm El-Ewa, F̄̄ Ușūl al-Niẓām al-Jinā' '̄ alIslāmī (al-Qāhirah: Dār al-Ma‘ārif, 1979), 239.

34 Lihat perbincangan lebih lanjut dalam: Abū al-Ma'āṭ̂̀ Hāifiz Abū alFutuh, al-Niz̄ām al-'Iqābī al-Islāmī (al-Qāhirah: Dār al-Ta'āwun, 1976), 418. 
tidak pernah berbangkit dalam pengajian fiqh klasik tetapi asas untuk ianya berbangkit memang ada. Fenomena ini dapat dilihat melalui berbagai definisi terhadap diyat yang diberikan oleh para fuqaha berkenaan seperti mana yang dinukilkan di atas. Sebahagian daripada mereka mengatakan diyat itu merupakan ganti rugi nyawa atau kecederaan, sementara sebahagian lain berpendapat ianya sebagai kesiksaan yang dikenakan sebagai balasan terhadap jenayah yang dilakukan. Lebih-lebih lagi apabila persoalan ini dibincangkan dalam konteks undang-undang Malaysia sekarang yang menentukan prosedur yang berbeza bagi kes-kes jenayah dan kes-kes sivil.

Mengikut kitab-kitab fiqh klasik, hukuman yang dikenakan keatas kes jenayah itu sifatnya "kesiksaan" (عقابي). dilihat pada hukuman Qisas atau hukuman-hukuman Hudud dalam kes-kes jenayah Hudud. Sedangkan diyat tidak mempunyai sifat kesiksaan yang jelas. Malah ia lebih jelas merupakan ganti rugi kerana sifat bayarannya yang ada. Mungkin kerana kesamaran yang terdapat pada diyat dan sebagainya ini jarang sekali para fuqaha klasik memberi definisi "jenayah" secara menyeluruh. Sebahagian besar dari mereka lebih suka memberi definisi secara berasingan terhadap kes-kes Qisas dan diyat. Begitu juga terhadap kes-kes Hudud daripada mendefinisikan semua kesalahan itu dalam satu definasi sahaja di bawah istilah "Jenayah". Hanya sebahagian kecil sahaja daripada mereka yang memberikan definisi secara menyeluruh bagi kesalahan-kesalahan itu di bawah istilah "jenayah", iaitu seperti mana yang dilakukan oleh al-Mawardi ${ }^{36}$.

Antara sifat lain bagi hukuman jenayah ialah ia tidak boleh dimaafkan, terutama oleh individu terlibat kerana ia termasuk dalam jumlah "hak Allah/masyarakat" (حقوق الله / البحتمع).37 Sedangkan diyat boleh digugurkan oleh pihak mangsa sama ada secara begitu sahaja atau berasaskan persetujuan lain, iaitu "șulh" (صلح). Kerana ia merupakan hak individu. ${ }^{38}$

35 Lihat: Al-Kāsān̄̄. Badā'’ $i$ (al-Qāhirah: al-Jamāliyyah, 1328H), 7:5663; Ibn ‘Ābidīn, Hāshiyah, 6:3.

36 Lihat: Al-Mawardī, al-Aḥkām al-Sultāniyyah (al-Qāhirah: alSa'ādah, 1327), 129.

37 Lihat: Al-Kāsānī, Badā'i', 7:5663; Ibn 'Ābidīn, Hāshiyah, 4:3.

38 Lihat: Al-Zayla'ī, Tabȳ̄n al-Haqā’iq (al-Qāhirah: Bulāq,1313H), 2:330; Al-Mawardī, al-Ahkām al-Sulțāniyyah, 219. 
Mengikut fiqh klasik lagi, pendakwaan dalam kes-kes kematian dan kecederaan ini akan dilakukan oleh pihak mangsa sendiri, iaitu diri atau keluarganya. ${ }^{39}$ Sedangkan dalam undang-undang di Malaysia sekarang pendakwaan dalam kes jenayah perlu dilakukan oleh pihak pendakwa raya dan tidak boleh dilakukan oleh orang perseorangan.

Semuanya ini memberi erti bahawa persoalan seperti ini perlu diselesaikan terlebih dahulu dari sudut pandangan fiqh. Kerana undang-undang Islam akan ditentukan peruntukannya berdasarkan kepada pandangan fiqh yang ada. Bagaimanapun, seperti mana yang telah ditegaskan di atas tidak semua jawapan yang diperlukan itu ada dalam fiqh klasik. Maksudnya, ia memerlukan penyelidikan baru yang mengambil kira faktor semasa dan setempat. Dengan kata lain, ia perlu kepada fiqh baru yang biasa dinamakan sebagai fiqh semasa dan setempat.

\section{KAEDAH BAYARAN}

Satu persoalan lain ialah jenis harta yang boleh dijadikan asas kepada bayaran tersebut. Mengikut majoriti para fuqaha, termasuk para fuqaha mazhab Shafii, ia mesti dalam bentuk unta. Pandangan ini berdasarkan kepada hadis-hadis Rasulullah SAW yang menyebut tentang hukuman berkenaan secara jelas dan terperinci. ${ }^{40}$

Persoalannya, dalam sebuah negara seperti Malaysia sekarang dari mana unta-unta itu mungkin diperolehi? Selain itu, berapa banyak wang yang perlu dibelanjakan untuk mendapatkan jumlah seperti mana yang tersebut dalam hadis Rasulullah SAW yang memperkatakan tentang diyat? Dalam keadaan seperti ini

39 Lihat: Al-Kāsān̄̄, Badā'i ‘, 7:87; Ibd Rushd, Bidāyah al-Mujtahid (al-Qāhirah: al-Kulliyyah al-Aẓhariyyah, 1966), 2:421; al-Sharbīn̄̄ al-Khațīb, Mughnī al-Muḥtāj (al-Qāhirah: al-Bābī, 1957), 4:114.

40 Lihat Hadis 'Amru Ibn Shu'aib dalam: al-Tirmīdhī, Sunan alTirmīdhī (Bayrūt: Dār Ihyyā' al-Turāth al-'Arabī, t. t.), 4:11; Abū Dāwūd, Sunan Abī Dāwūd (Bayrūt: Dār Ihyā’’ al-Turāth al-'Arab̄i, t. t.), 4:186. 
para fuqaha berkenaan berpendapat ia boleh digantikan dengan harganya. ${ }^{41}$

Bagaimanapun satu pendapat lain mengatakan unta bukan menjadi asas paling utama kepada bayaran berkenaan. Bagi mereka, ia sekadar salah satu dari tiga perkara asas. Dua lagi ialah wang emas (dinar) dan wang perak (dirham). ${ }^{42}$ Maksudnya, diyat boleh dibayar dalam bentuk salah satu daripada tiga harta utama berkenaan tanpa terikat kepada unta. Asas kepada pandangan mereka ini ialah athar daripada Umar RA yang menyebut ketigatiganya boleh menjadi asas kepada pembayaran berkenaan. ${ }^{43}$ Antara alasan lain yang mereka berikan ialah wang emas dan wang perak adalah bernilai tetap dan tidak berubah sama seperti unta. ${ }^{44}$

Malah mengikut pendapat lain lagi, diyat boleh dibayar dalam bentuk salah satu daripada enam jenis harta iatu unta, emas, perak, lembu, kambing dan pakaian. ${ }^{45}$ Pendapat ini berasaskan kepada hadis Rasulullah SAW yang menyebut Baginda pernah memutuskan diyat perlu dibayar dalam bentuk-bentuk harta berkenaan sesuai dengan pemilikan masing-masing. ${ }^{46}$ Maksudnya, ia boleh dibayar dengan apa saja yang termasuk dalam takrif harta pada waktu itu.

Kepelbagaian pendapat ini menggambarkan bahawa ketentuan jenis harta yang boleh dijadikan sebagai asas kepada pembayaran diyat itu bukan berdasarkan kepada hadis Rasulullah SAW yang menyebut secara jelas. Sebaliknya terdapat hadis-hadis yang menjelaskan berbagai cara bayaran mengikut keadaan. Dalam mentafsirkan kehendak hadis-hadis berkenaan para ulama berbeza pendapat. Hal ini membuka jalan kepada para ilmuan Islam zaman

41 Lihat: Muhammad Najīb Muți'ì, Mukammilāt al-Majmū' li al-Imām al-Nawawì (al-Qāhirah: Jeddah, Maktabah al-Irshād, t. t.), 20:463.

42 Lihat: Al-Kāsānī, Badā' ' $i, 304$.

43 Diriwayatkan oleh Anās Ibn Mālik.

44 Lihat: Al-Jașșāṣ, Ahkām al-Qur'ān (Bayrūt: Dār al-Fikr, 1993), 2:332-333.

45 Lihat: Abū Yūsuf, Kitāa al-Kharāj (Bayrūt: Dār al-Ma‘rifah, t. t.).

46 Hadis riwayat Abū Dāwūd. Lihat: Abū Dāwūd, Sunan Abī Dāwūed, 183. 
ini mentafsirkan kembali hadis-hadis berkenaan berdasarkan realiti semasa dan setempat yang kita hayati sekarang.

\section{KONSEP ' $\bar{A} Q I L A H$}

Dalam sesetengah kes, iaitu kes-kes menyebabkan kematian atau kecederaan tanpa niat, pihak yang kena bayar diyat bukannya pesalah itu sendiri tetapi kaum keluarganya. ${ }^{47}$ Dalam fiqh klasik, kaum keluarga ini disebut sebagai 'āqilah. Ia merujuk kepada satu sistem kekeluargaan yang terdapat pada zaman Rasulullah SAW iaitu yang diwarisi sejak zaman berzaman lagi dalam masyarakat Arab. ${ }^{48}$

Secara ringkasnya, 'āqilah bermaksud orang yang bertugas menambat unta diyat di pekarangan rumah mangsa pembunuhan berkenaan. Ia biasanya terdiri daripada orang tertentu dalam keluarga pembunuh. Dalam menentukan senarai mereka yang terlibat dalam konsep 'āqilah ini para ulama tidak sependapat. Kerana ketentuan berkenaan merujuk kepada adat yang berlaku pada zaman itu. Namun konsepnya ialah mereka yang memikul tanggungjawab bersama dalam keluarga berkenaan dalam menghadapi apa-apa masalah. Hampir dengan konsep ini ialah konsep takaful yang dijadikan asas kepada insuran patuh syariah pada hari ini.

Bagaimanapun, sistem ini atau yang serupa dengannya tidak lagi wujud sekarang, termasuk dalam masyarakat Arab sendiri. ${ }^{49}$ Realiti ini memerlukan penilaian semula konsep berkenaan dalam realiti hidup sekarang. Dalam membuat penilaian semula ini rujukan perlu dibuat terhadap ayat-ayat al-Quran dan hadis-hadis Rasulullah SAW yang memperkatakan tentang perkara berkenaan. Dalam memperdalamkan kefahaman tentang konsep-konsep yang

47 Lihat: Hadis Rasulullah SAW seperti mana yang diriwayatkan oleh Abū Hurayrah dalam al-Isfaraynī, Musnad Abī 'Uwānah (Bayrūt: Dār al-Ma'rifah, 1998), 108.

48 Lihat: Tawfīq Bar, Tārīkh al- 'Arab al-Qadīm (Damshiq: Dār al-Fikr, 1984), 252; Hassan Ibrāhim Hasan, Tārīkh al-Islām al-Siyāsī (alQāhirah: Maktabah al-Nahḍah al-Mișriyyah, 1964), 52-53.

49 Lihat: Yūsuf al-Qaraḍāwī, al-Fiqh al-Islāmī Bayn al-Ișālah wa alTajdìd, ed. ke-2 (al-Qāhirah: Maktabah Wahbah, 1999). 
dimaksudkan itu rujukan boleh dibuat terhadap pendapat para fuqaha sebagai sumber sejarah kepada pentafsiran yang berkaitan. Kemudian semuanya ini perlu dipadankan dengan realiti hidup semasa agar kesimpulan yang dibuat bersifat realistik seperti mana yang diperlukan oleh "fiqh" dalam konsepnya yang sebenar.

\section{PENUTUP}

Seperti mana yang berlaku dalam bidang kewangan Islam pada suatu masa dahulu, percubaan untuk mengembalikan semula hukum Islam, seperti diyat ini ke persada masyarakat sebagai undang-undang dan peraturan yang terlaksana mungkin dilihat sebagai ganjil. Kata-kata yang penuh prajudis yang biasa terdengar sehubungan dengan usaha murni ini seperti "Apakah kita akan membawa kembali hukum dan peraturan zaman unta bagi direalisasikan pada zaman sains dan teknologi ini?" Nyata sekali ia merupakan langkah undur kebelakang.

Kegagalan bank Islam pertama yang ditubuhkan di Mit Ghamrah, Mesir kemudiannya ditunjuk sebagai bukti tentang kebenaran kata-kata berkenaan dan ia bukanlah sebagai suatu prajudis semata-mata. Namun, kemudiannya dengan usaha yang gigih membaiki segala kesilapan yang ada perbankan Islam yang mulanya dilihat sebagai cita-cita Mat Jenin itu telah muncul sebagai satu sistem kewangan yang unggul dan dihormati di seluruh dunia sekarang. Dengan kejayaan itu satu bukti telah berjaya dikemukakan, iaitu peraturan Islam yang kadangkadangnya dianggap terlalu lama dan usang itu mampu berfungsi kembali dengan prestasi yang sangat baik apabila diberi peluang yang saksama untuknya berfungsi kembali.

Begitu pun, kegagalan dan kejayaan perbankan Islam juga mengajar kita bahawa ada prasyarat tertentu yang boleh memperdekatkan usaha seperti itu kepada kejayaan. Prasyarat tersebut, antaranya ialah menilai semula keputusan-keputusan yang terdapat dalam kitab-kitab fiqh klasik dengan merujuk kembali prinsip-prinsip asal yang terdapat dalam al-Quran dan al-Sunnah dan kemudiannya merealisasikan prinsip-prinsip berkenaan berasaskan realiti hidup yang ada. Dalam bahasa para fuqaha zaman sekarang usaha seperti ini disebut sebagai Tajdid 
atau reformasi pemikiran hukum Islam berasaskan prinsip semasa dan setempat. Sementara hasil usaha seperti ini disebut sebagai "fiqh semasa".

Kembali kepada diyat yang menjadi tajuk kepada perbincangan dalamkertas ini, antara prasyaratyang boleh menjamin kejayaannya bila dilaksanakan ialah penilaian kembali segala ketentuan yang ada di dalamnya dengan merujuk semula kepada al-Quran dan alSunnah dan kemudian merealisasikannya dalam realiti hidup yang ada. Dengan kata lain, jurang zaman yang terdapat dalam fiqh klasik yang lama itu perlu diperdekatkan agar ia lebih realistik dalam realiti yang ada.

Cara melakukan penilaian semula itu telah digalurkan dengan jelas oleh para fuqaha zaman sekarang dengan berpandukan prinsip dan sejarah perundangan Islam yang sedia ada. Secara umumnya usaha seperti ini biasa disebut sebagai ijtihad semasa. Namun sekiranya istilah berkenaan boleh menimbulkan sensitiviti dalam kalangan sesetengah pihak, maka istilah berkenaan boleh ditukar menjadi "penyelidikan semasa".

Antara faktor baru yang penting dalam kerja penyelidikan semasa ini ialah kefahaman terhadap realiti hidup, atau secara popularnya disebut sebagai " fiqh al-wāqi" " seperti mana yang dianjurkan oleh Yūsuf al-Qaraḍāwī. Ia merupakan perkara kedua yang terpenting dalam usaha ijtihad atau penyelidikan tentang hukum sesudah kefahaman terhadap nas Syarak, iaitu yang diistilahkan sebagai "fiqh al-nușūṣ". Namun semua ini tidak bererti penolakan secara total terhadap kefahaman lama yang sedia ada dalam kitab-kitab fiqh klasik. Kerana dalam apa keadaan sekalipun pendapat-pendapat itu tetap menjadi sumber sejarah kepada kefahaman baru yang akan dibentuk itu. Malah mungkin ada yang perlu dikekalkan, misalnya kalau pola pemikiran berkenaan mencapai tahap universalisme yang tinggi sehingga merentasi zaman. 


\section{BIBLIOGRAFI}

Abū al-Futuh, al-Ma'āṭī Hiâfiz. Al-Nizāam al-'Iqābī al-Islāmī. AlQāhirah: Dār al-Ta‘āwun, 1976.

Abū Dāwūd. Sunan Abī Dāwūd. Bayrūt: Dār Iḥyā’ al-Turāth al'Arabī, t. t.

Abū Yūsuf, Ya'qūb Ibn Ibrāhim. Kitāb al-Kharāj. Bayrūt: Dār alMa'rifah, t. t.

Abū Zahrah, Muhammad. F̄̄ Tārikh al-Madhāhib al-Fiqhiyyah. Al-Qāhirah: Dār al-Fikr al-'Arab̄i, t. t.

Aḥmad, Hasan Șubhī. Al-Madkhal ilā al-Fiqh al-Islāmī. AlQāhirah: Mațba'ah al-Risālah, 1971.

Al-Ashqar, 'Umar Sulaymān. Tārīkh al-Fiqh al-Islāmī. Ed. ke-3. 'Ammān: Dār al-Nafā'is, 1991.

Al-Bukhārī. Șaḥ̄ḥ al-Bukhārī. Bayrūt: Dār Iḥyā' al-Turāth al'Arabī, 2001.

Al-Būṭ̂̄, Sa'īd Ramaḍān. Rawḍ al-Murabbā'. Riyāḍ: Maktabah al-Riyāḍ al-Hadīthah, $1390 \mathrm{H}$.

Al-Jașșāṣ, Abū Bakr. Ahkām al-Qur'ān. Bayrūt: Dār al-Fikr, 1993.

Al-Kāsānī, 'Alā' al-Dīn Abū Bakr Ibn Mas'ūd. Badā'i'. AlQāhirah: al-Jamāliyyah, 1328H.

Al-Khațīb, al-Sharbīnī. Mughnī al-Muhtāj. Al-Qāhirah: al-Bābī, 1957.

Al-Khuḍrī, Muḥammad. Tārīkh al-Tashrī‘ al-Islāmī. Ed. ke-6. Al-Qāhirah: Maktabah al-Tijāriyyah al-Kubrā, 1964.

Al-Mālikī, Abū al-Ḥasan. Kifāyat al-Ṭālib. Bayrūt: Dār al-Fikr, $1412 \mathrm{H}$.

Al-Mawardī, Abū al-Ḥasan. Al-Ahkā̄m al-Sulțāniyyah.Al-Qāhirah: al-Sa'ādah, 1327. 
Al-Qaraḍāwī, Yūsuf. Al-Fiqh al-Islāmī Bayn al-Ișālah wa alTajdīd. Al-Qāhirah: Maktabah Wahbah, 1999.

Al-Ramlī, Shams al-Dīn. Nihāyah al-Muhtāj.Al-Qāhirah: Muștafā al-Ḥalabī, t. t.

Al-Shāi ‘̄̄, Muhammad Ibn Idrīs. Al-Umm. Al-Qāhirah: Dār alGhad, 1990.

Al-Shahrastānī. al-Milal wa al-Nihal. Al-Qāhirah: Maṭba'ah Hijāzīi, 1949.

Al-Shawkānī, Muḥammad Ibn 'Alī. Nayl al-Awțār. Bayrūt: Dār al-Fikr, 1983.

Al-Tabrīzī, Al-Khațīb. Mishkāt al-Mașābihh. Ed. Nāṣr al-Dīn alAlbānī. Bayrūt: al-Maktab al-Islāmī, 1969.

Al-Tirmīdhī. Sunan al-Tirmīdhī. Bayrūt: Dār Iḥyā’ al-Turāth al'Arabī, t. t.

Al-Zayla'ī, Fakhr al-Dīn 'Uthmān Ibn 'Alī. Tabyìn al-Haqā'iq. Al-Qāhirah: Bulāq, 1313.

Al-Zuhaylī, Wahbah. Al-Fiqh al-Islāmī wa Adillatuh. Bayrūt: Dār al-Fikr al-Mu'āṣir, 1997.

Al-Zuhaylī, Wahbah. Naẓāriyyah al-Ḍamān. Damshiq: Dār alFikr, 1998.

Bahnasī, Ahmad Fatḥ̄. Al-Diyah fì al-Sharī'ah al-Islāmiyyah. AlQāhirah: Maktabah al-Anglow al-Islāmiyyah, 1967.

Bar, Tawfīq. Tārìkh al-'Arab al-Qadìm. Damshiq: Dār al-Fikr, 1984.

Hassan, Ibrāhim Hassan. Tārīkh al-Islām al-Siyāsī. Al-Qāhirah: Maktabah al-Nahḍah al-Mișriyyah, 1964.

Ḥusarī, Aḥmad. Al-Siyāsah al-Jaza'iyyah. Bayrūt: Dār al-Jayl, 1993.

Ibn 'Ābidīn, Muhammad Amīn. Hāshiyah Radd al-Muhtār 'alā al-Dur al-Mukhtār. Al-Qāhirah, Al-Bābī, 1966. 
Ibn al-Qayyim. I'lām al-Muwaqqi 'ìn. Al-Qāhirah: Maktabah alKulliyāt al-Azāhariyyah, 1968.

Ibd Rushd, Abū al-Walīd Muḥammad Ibn Aḥmad al-Qurțubī. Bidāyah al-Mujtahid. Al-Qāhirah: al-Kulliyyah alAẓhariyyah, 1966.

Mūsā, Muḥammad Yūsuf. Tārīkh al-Fiqh al-Islāmī. Al-Qāhirah: Dār al-Kitāb al-'Arab̄i, 1958.

Muslim. Șaḥīh Muslim. Bayrūt: Dār Iḥyā' al-Turāth al-'Arabī, 2000 .

Muțī'î, Muhammad Najib. Mukammilāt al-Majmū' li al-Imām alNawawī. Al-Qāhirah: Maktabah al-Irshād, t. t. 